\title{
Metody monitoringu i remediacji gruntów zanieczyszczonych rtęcią na terenach przemysłowych
}

\begin{abstract}
W artykule przedstawiono politykę ograniczania emisji rtęci do powietrza oraz informacje dotyczące występowania zanieczyszczeń rtęcią na terenach przemysłowych. Omówiono również możliwości zastosowania wskaźnikowych metod pośrednich podczas monitoringu terenów zanieczyszczonych rtęcią metaliczną oraz sposoby prowadzenia remediacji takich terenów.
\end{abstract}

Słowa kluczowe: rtęć, redukcja emisji rtęci, zanieczyszczenia gleb rtęcią metaliczną, metody monitoringu, metody remediacji.

\section{Monitoring and remediation techniques for mercury-contaminated soil in industrial areas}

\begin{abstract}
The article presents policy regarding the reduction of mercury emissions into the air and information on the presence of mercury pollution in industrial areas. It also briefly discusses the applicability of indirect data-based methods during monitoring of metallic mercury-contaminated areas and remediation techniques for such sites.
\end{abstract}

Key words: mercury, reduction of mercury emissions, metallic mercury-contaminated soil, monitoring techniques, remediation techniques.

\section{Wprowadzenie}

Rtęć to pierwiastek szkodliwy i toksyczny, a jego negatywny wpływ na środowisko oraz zdrowie i życie ludzi budzi na świecie szerokie zainteresowanie i dyskusje od wielu już lat. W środowisku pierwiastek ten występuje w formie metalicznej oraz w postaci związków organicznych i nieorganicznych. Jego obecność wykazywana jest we wszystkich elementach środowiska (w wodzie, glebie i powietrzu), a źródło pochodzenia może być naturalne lub antropogeniczne.

Przegląd informacji dotyczących gospodarowania rtęcią i strategii związanej z wykorzystaniem tego pierwiastka pokazuje, że od ponad 20 lat prowadzona jest szeroko zakrojona światowa polityka ograniczania emisji rtęci do różnych elementów środowiska naturalnego.
Ograniczanie emisji rtęci do środowiska opiera się głównie na wprowadzaniu zmian w procesach technologicznych, zmniejszeniu podaży i popytu na materiały zawierające rtęć oraz zaostrzeniu polityki związanej z gospodarowaniem odpadami zawierającymi ten pierwiastek. W Polsce zredukowane zostały na przykład emisje do środowiska z przemysłu chloroalkalicznego i opracowano strategie BAT (best available techniques - najlepsze dostępne techniki) tego typu działalności. Wprowadzenie technologii membranowych doprowadziło w konsekwencji do drastycznego obniżenia emisji rtęci do środowiska z tej gałęzi przemysłu [16].

Regulacje prawne związane z proekologicznym gospodarowaniem rtęcią są wydawane na poziomie światowym, Unii Europejskiej i krajowym. Dokumentem najbardziej kompleksowo 
obejmującym problem ograniczania emisji rtęci jest podpisana w 2014 roku konwencja z Minamaty. Jej postanowienia regulują takie zagadnienia jak: podaż, handel, produkty z dodatkami rtęci, emisja do powietrza, górnictwo złota na małą skalę, uwolnienia do wody i ziemi, odpady, miejsca zanieczyszczone, pomoc techniczna i finansowa, wymiana informacji, świadomość społeczna i edukacja, badania i monitoring, aspekty zdrowotne, plany wdrożeniowe oraz raportowanie $[4,10,26]$. W dokumencie tym przedstawiono również światową politykę ograniczenia emisji rtęci do środowiska w perspektywie wieloletniej.

Mimo działań podjętych na ogólnoświatowym poziomie największym emitorem rtęci do środowiska wciąż pozostaje przemysł energetyczny, a zwłaszcza instalacje, w których spalane są węgle kamienny i brunatny $[3,5]$. Dodatkowo jednak w świetle rozwijających się ograniczeń wielkości emisji rtęci i stosowania zamiennych technologii niewykazujących zdolności do emisji tego pierwiastka zaczęto również zwracać uwagę na te sektory przemysłu, w których emisja rtęci w porównaniu do największych emitorów tego pierwiastka do środowiska była zaniedbywalnie mała. W sprawozdaniu UNEP (United Nations Environment Programme) z 2013 roku po raz pierwszy wskazano na brak danych o emisji rtęci do środowiska m.in. w sektorze wydobycia, przetwarzania i transportu ropy naftowej i gazu ziemnego [24]. Zwrócono uwagę, że pomimo istnienia instalacji wydobycia gazu ziemnego i ropy naftowej, na których funkcjonują procesy oczyszczania tych surowców kopalnych z rtęci, nie ma zbyt wielu dostępnych informacji na temat ewentualnej emisji tego pierwiastka do atmosfery [24].

\section{Zanieczyszczenia rtęcią na terenach przemysłowych}

Na rodzimym rynku przemysłowym emisja rtęci i zanieczyszczenia środowiska tym pierwiastkiem występowały lub występują głównie w związku z działalnością przemysłów chloroalkalicznego, energetycznego oraz dentystyki. Problem lokalnych zanieczyszczeń rtęcią istnieje również na terenach poszukiwania i eksploatacji złóż węglowodorów.

Największy udział w rocznej emisji rtęci do powietrza w Polsce ma obecnie przemysł energetyczny, wykorzystujący jako surowiec stałe paliwa kopalne, takie jak węgiel kamienny i brunatny. Emisje w tym sektorze gospodarki związane są ze spalaniem węgla zawierającego znaczące ilości rtęci. Opisane w literaturze badania wykazały, że zawartość rtęci w spalanym w Polsce węglu kamiennym może wahać się od 0,095 do $0,615 \mathrm{mg} / \mathrm{kg}$, natomiast w węglu brunatnym w granicach od 0,080 do $0,250 \mathrm{mg} / \mathrm{kg}[5,7,11,20,21]$. Należy jednak zaznaczyć, że ograniczanie emisji rtęci z procesów spalania węgli to odrębna tematyka, rozpatrywana w aspekcie modyfikacji technologii procesów spalania i oczyszczania spalin.

Pozostałe paliwa (ropa naftowa i gaz ziemny) mogą również zawierać rtęć, jest ona jednak zwykle usuwana w procesie ich oczyszczania. Zarówno ropa naftowa, jak i gaz ziemny, o ile zawierają rtęć, muszą być oczyszczane w procesie obróbki wstępnej. Zawartość rtęci w ropie naftowej zmienia się w zależności od miejsca pochodzenia tego paliwa. Informacje na temat naturalnej zawartości rtęci w ropie naftowej są zróżnicowane, a oznaczone stężenia mieszczą się w przedziale od 0,4 do $1500 \mu \mathrm{g} / \mathrm{kg}$ [2], a nawet $30 \mathrm{mg} / \mathrm{kg}[18,22]$. Zestawienie zakresów możliwej zawartości rtęci w wydobywanych w Europie i na świecie gazie ziemnym i ropie naftowej przedstawiono w tablicach 1 i 2.

Dane przedstawione $\mathrm{w}$ tablicach 1 i 2 pokazują, że zarówno w Europie, jak i na świecie występują złoża gazu
Tablica 1. Zestawienie zakresów możliwej zawartości rtęci w gazie ziemnym i kondensacie węglowodorowym w zależności od obszaru wydobycia [2]

\begin{tabular}{|l|c|c|}
\hline \multicolumn{1}{|c|}{ Obszar } & $\begin{array}{c}\text { Zawartość rtęci } \\
\text { w gazie } \\
{\left[\mu \mathrm{g} / \mathrm{m}^{3}\right]}\end{array}$ & $\begin{array}{c}\text { Zawartość rtęci } \\
\text { w kondensacie } \\
\text { węglowodorowym } \\
{[\mu \mathrm{g} / \mathrm{kg}]}\end{array}$ \\
\hline Europa & $100 \div 150$ & - \\
\hline Południowa Afryka & $50 \div 120$ & $50 \div 100$ \\
\hline Zatoka Tajlandzka & $100 \div 400$ & $400 \div 1200$ \\
\hline Afryka & $80 \div 100$ & $500 \div 100$ \\
\hline Zatoka Meksykańska & $0,02 \div 0,4$ & - \\
\hline Północna Afryka & $50 \div 80$ & $20 \div 50$ \\
\hline Malezja & $1 \div 200$ & $10 \div 100$ \\
\hline Indonezja & $200 \div 300$ & $10 \div 500$ \\
\hline
\end{tabular}

Tablica 2. Zestawienie przykładowej zawartości rtęci w gazach wydobywanych w Polsce i na świecie $[6,12]$

\begin{tabular}{|l|c|c|}
\hline \multirow{3}{*}{ Kraj } & Złoże & $\begin{array}{r}\text { Zawartość rtęci } \\
\text { w gazie } \\
{\left[\mu \mathrm{g} / \mathrm{m}^{3}\right]}\end{array}$ \\
\hline \multirow{3}{*}{ Polska } & Racot & 100 \\
\cline { 2 - 3 } & Bonikowo & 210 \\
\cline { 2 - 3 } & Kościan & 226 \\
\cline { 2 - 3 } & Radlin & 200 \\
\hline Niemcy & Paproć & 350 \\
\hline Holandia & - & $450 \div 5000$ \\
\hline Norwegia & Groningen & $180 \div 200$ \\
\hline Indonezja & Arun & $250 \div 300$ \\
\hline Niger & Niger Delta & 10 \\
\hline Trynidad & Nort \& East Coast & 12 \\
\hline Australia & Goodwin, North Rankin & 38 \\
\hline Oman & Saih Nihayda \& Saih Rawl & 60 \\
\hline
\end{tabular}


zawierającego rtęć. Najczęściej stężenie tego pierwiastka w wydobywanym gazie jest nieistotne, ale istnieją również złoża, w których oznaczana zawartość rtęci w gazie sięga poziomu kilkuset, a nawet kilku tysięcy $\mu \mathrm{g} / \mathrm{m}^{3}$ gazu $[2,6,12]$. Oznacza to, że przy otworowej eksploatacji złóż węglowodorów mogą występować lokalne zanieczyszczenia środowiska rtęcią, w szczególności w obrębie miejsc wydobycia gazu zawierającego ten pierwiastek. Do przenikania rtęci do elementów środowiska na terenach związanych z górnictwem nafty i gazu może dochodzić w czasie prowadzenia takich prac jak:

- wiercenie otworów (możliwość powstania odpadów zawierających podwyższone zawartości rtęci),

- wstępna separacja gazu (możliwość emisji),

- osuszanie i oczyszczanie gazu (możliwa obecność rtęci w odpadach ciekłych i substancjach sorbujących) $[1,6,13]$.

W Polsce zanieczyszczenie gazu ziemnego rtęcią może sięgać nawet kilkuset $\mu \mathrm{g} / \mathrm{m}^{3}$. Jednak prawo polskie ogranicza dopuszczalną zawartość rtęci w gazie ziemnym transportowanym w systemie przesyłowym i dystrybucyjnym tego paliwa. Limit ten wynosi w przypadku obu systemów $30 \mu \mathrm{g} / \mathrm{m}^{3}$ rtęci w gazie. Parametr ten jest ściśle kontrolowany zgodnie z rozporząadzeniem Ministra Gospodarki z dnia 2 lipca 2010 r. w sprawie szczegółowych warunków funkcjonowania systemu gazowego [29], a sposób kontroli został dokładnie opisany w polskich normach PN-C-04752:2011 oraz PN-C-04753:2011 [27, 28].

$\mathrm{Z}$ uwagi na dopuszczalną zawartość rtęci w przesyłanym i dystrybuowanym paliwie oraz właściwości korozyjne rtęci (które mogłyby mieć negatywny wpływ na stan urządzeń wydobywczych, rurociągów i instalacji kopalnianych) gaz pochodzący ze złóż o podwyższonej zawartości rtęci przed wprowadzeniem do systemu gazowego musi być poddany technologii oczyszczania z rtęci [1, 6]. Opracowano już wiele technologii odrtęciania gazu [13], przy wykorzystaniu metod fizycznych (kondensacja i okluzja), chemicznych (reakcja chemiczna na sorbencie stałym, ciekłym lub gazowym) oraz fizykochemicznych.
W Polsce zanieczyszczenie środowiska glebowego rtęcią może wystąpić na terenach po byłych gazowniach i wiertniach oraz na terenach kopalń ropy i gazu ziemnego (zwłaszcza tam, gdzie wydobywane są surowce wymagające oczyszczania z rtęci) [15]. Znacząca ilość tego pierwiastka może również znajdować się w odpadach powstających podczas wiercenia otworów poszukiwawczych i eksploatacyjnych w obrębie złóż węglowodorów zawierających rtęć. Jednak pomimo stosowania na skalę przemysłową podczas poszukiwania i eksploatacji złóż węglowodorów niskoemisyjnych i bezpiecznych dla środowiska technologii - na terenach kopalń gazu ziemnego, gdzie gaz jest poddawany procesom odrtęciania, odnotowano lokalne zanieczyszczenia gleby tym pierwiastkiem. Zanieczyszczenia zostały stwierdzone w glebie wokół zespołów zaporowo-upustowych, węzłów redukcyjno-pomiarowych, urządzeń służących do odrtęciania gazu oraz w okolicach zbiorników i oddzielaczy wody złożowej. Zawartość rtęci w glebie, oznaczona na terenie jednej z kopalń w okolicach wspomnianych już miejsc, sięga nawet kilkuset $\mathrm{mg} / \mathrm{kg}$ s.m., przy dopuszczalnym stężeniu rtęci w glebach dla obszarów klasy C na poziomie $30 \mathrm{mg} / \mathrm{kg}$ s.m. Należy również zauważyć, że w odniesieniu do sytuacji z początku XXI wieku zmieniła się zdecydowanie technologia pomiarowa, wyeliminowane zostały z linii technologicznych wszelkiego rodzaju manometry rtęciowe, które często mogły być przyczyną i źródłem zanieczyszczenia gleby rtęcią na obszarze ich stosowania. Natomiast dostępne wyniki badań z terenów po składowaniu odpadów wydobywczych (okolice starych dołów urobkowych) nie wskazują na przekroczenie dopuszczalnej zawartości rtęci w glebie, co pozwala stwierdzić, że zawartość tego pierwiastka w odpadach jest niska $[14,15]$.

Potencjalne obszary zanieczyszczenia rtęcią przedstawione w przypadku obiektów z terenu Polski pokrywają się $z$ danymi prezentowanymi dla obszarów ocenianych jako potencjalnie zanieczyszczone tym pierwiastkiem na obiektach w Wielkiej Brytanii, Norwegii i Malezji [17, 19].

\section{Metody monitoringu gleb zanieczyszczonych rtęcią}

Rozpoznawanie, a następnie oczyszczanie obszarów o niewielkim zasięgu zanieczyszczenia, na których emisja rtęci metalicznej może być cykliczna, wymaga indywidualnego podejścia, innego niż te zalecane w przypadku dużych obszarów zdegradowanych. Również diagnostyka tego typu niewielkich obszarowo miejsc zanieczyszczonych rtęcią jest trudna, niekiedy czasochłonna i wiąże się często z koniecznością zagęszczenia siatki pomiarowej (obok obszarów całkowicie pozbawionych zanieczyszczeń mogą występować miejsca bardzo zanieczyszczone). W związku z tym podczas prowadzenia monitoringu obszarów lokalnie zanieczyszczonych rtęcią istotne jest zastosowanie prostej metody wskaźnikowej jako metody przesiewowej służącej do identyfikacji tych niewielkich obszarowo miejsc zanieczyszczonych rtęcią metaliczną.

W ramach prac INiG - PIB opracowano system monitorowania miejsc potencjalnie zanieczyszczonych rtęcią metaliczną. Pierwszym etapem prowadzenia monitoringu jest wywiad i zebranie informacji dotyczących stosowanego na ocenianym obszarze procesu technologicznego. Niezbędne 
do dalszych badań i pomiarów dane powinny obejmować informacje na temat:

- powierzchni i zasięgu terenu objętego badaniami,

- rozmieszczenia poszczególnych elementów procesu technologicznego,

- jakości wydobywanego paliwa (informacje o zawartości rtęci w gazie nieoczyszczonym i oczyszczonym),

- stosowanej technologii oczyszczania gazu,

- położenia miejsc, w których prawdopodobieństwo przedostania się rtęci do środowiska jest największe (np. w przypadku prowadzenia oceny stanu środowiska na terenie kopalni gazu ziemnego należy zwrócić szczególną uwagę na lokalizację zespołów zaporowo-upustowych i węzłów redukcyjno-pomiarowych, gdyż to właśnie te miejsca stanowić mogą największe źródło emisji rtęci do środowiska),

- częstotliwości kontrolowanych upustów gazu (czy jest to ewidencjonowane, czy nie; informacja ta ułatwi określenie cykliczności wprowadzania rtęci do elementów środowiska) oraz

- sąsiedztwa cieków wodnych.

W drugim etapie powinny zostać wytypowane miejsca do pobrania próbek gleby/gruntu oraz powinny zostać przeprowadzone pomiary polowe wielkości emisji rtęci do powietrza na ocenianym obszarze.

Metody prowadzenia monitoringu opracowane i zalecane przez INiG - PIB przewidują typowanie miejsc zanieczyszczonych rtęcią na podstawie wykonywania pomiarów wielkości emisji rtęci z powietrza glebowego z zastosowaniem czujników pasywnych i/lub metodą komór dyfuzyjnych. Schemat miejsc prowadzenia pomiarów powinien obejmować cały obszar wytypowany do badań, ze szczególnym uwzględnieniem tych lokalizacji, gdzie prawdopodobieństwo wystąpienia zanieczyszczenia rtęcią jest największe (na tych obszarach powinna zostać zagęszczona siatka punktów, w których rozstawione zostaną czujniki pasywne i/lub komory dyfuzyjne).
Takie działanie jest konieczne ze względu na zwykle niejednorodny charakter zanieczyszczenia gleby rtęcią metaliczną.

Następnie na podstawie oceny wyników pomiarów wielkości emisji rtęci z ocenianego obszaru powinny zostać wytypowane miejsca poboru próbek gleby/gruntu do badań. Schemat pobierania tych próbek powinien również obejmować cały obszar wyznaczony do badań, ze szczególnym uwzględnieniem miejsc, w których prawdopodobieństwo wystąpienia zanieczyszczenia rtęcią jest największe (na tych obszarach powinna zostać zagęszczona siatka pobierania próbek jednostkowych). Próbki gleby/gruntu do badań powinny być pobrane w taki sposób, aby można było ocenić badany obszar zgodnie z wytycznymi zawartymi w załączniku do rozporządzenia Ministra Środowiska z dnia 9 września 2002 r., określonymi dla terenów przemysłowych (grupa C) [32].

Należy dodać, że zwykle ze względu na charakter zanieczyszczenia gleby/gruntu rtęcią metaliczną analizie na zawartość tego pierwiastka w pierwszej kolejności powinny zostać poddane próbki pochodzące z warstwy wierzchniej, a dopiero w przypadku stwierdzenia w nich zanieczyszczenia celowe jest oznaczanie zawartości rtęci w warstwach głębszych. Taki sposób postępowania jest uzasadniony, jeżeli analiza procesu technologicznego wykaże, że rtęć do gleby przedostaje się podczas np. niekontrolowanych upustów gazu do powietrza atmosferycznego.

Przeprowadzenie, zgodnie z przedstawionymi wytycznymi, oceny stanu gleby/gruntu pozwala na uzyskanie miarodajnych wyników bez konieczności zagęszczania siatki pobierania próbek gleby/gruntu w miejscach, gdzie pomiary wielkości emisji nie wykazały potencjalnych zanieczyszczeń. Wykonane przez INiG - PIB, zgodnie z opracowanym schematem, badania w obrębie instalacji uzdatniania węglowodorów na kopalniach gazu ziemnego wykazały, że zanieczyszczenie dotyczy miejsc niewielkich obszarowo i występuje praktycznie tylko w warstwie powierzchniowej gleby, do głębokości 0,6 m pod powierzchnią terenu.

\section{Metody remediacji gleb zanieczyszczonych rtęcią}

Ważnym zagadnieniem w kontekście identyfikacji i następnie ograniczania rozprzestrzeniania się zanieczyszczeń rtęcią w elementach środowiska jest dobór odpowiedniej metodyki oczyszczania gleby lub neutralizacji rtęci metalicznej w niej zawartej. Podczas doboru właściwej metody unieszkodliwiania rtęci w glebie na terenach przemysłowych konieczne jest uwzględnienie miejsca i charakteru występowania zanieczyszczeń.

Nie ma jednej prostej metody polowego oczyszczania gleby z rtęci, zwłaszcza z niewielkich obszarów. Można byłoby usuwać zanieczyszczoną glebę i zastępować ją glebą niezawierającą rtęci, ale tam, gdzie zanieczyszczenie powstaje na skutek technologicznych wydmuchów gazu zawierającego rtęć lub wycieków wody złożowej, byłoby to tylko rozwiązanie doraźne. W razie konieczności neutralizacji zanieczyszczenia w usuniętej glebie wymagany byłby jej transport do miejsca uzdatniania, a więc przypuszczalnie na dużą odległość. Koszty usunięcia zanieczyszczonej gleby, jej transportu i składowania oraz nawiezienia gleby niezanieczyszczonej mogłyby być znaczące. Z kolei, aby proces wymywania kwasami, desorpcji termicznej czy remediacji elektrokinetycznej był akceptowalny pod względem kosztów, musi być prowadzony 
w dużych instalacjach. Nie można zastosować również fitoremediacji, ponieważ zanieczyszczenia występują w bezpośrednim sąsiedztwie instalacji. Rozsądnym rozwiązaniem na tych niewielkich obszarach zanieczyszczonych rtęcią wydaje się zastosowanie metody immobilizacji rtęci w glebie za pomocą rozdrobnionej siarki. Metoda ta co prawda nie pozwala na usunięcie rtęci z gleby, ale powoduje ograniczenie dalszego rozprzestrzeniania się tej substancji w środowisku (migracji do wód i emisji do powietrza). Takie rozwiązanie problemu jest jak najbardziej zgodne $\mathrm{z}$ obowiązującym w Polsce prawodawstwem dotyczącym ograniczania rozprzestrzeniania zanieczyszczeń w środowisku [30, 31, 33, 34].

Stosując zabieg immobilizacji rtęci w glebie za pomocą rozdrobnionej siarki, należy dokonać okresowo oceny efektywności tego zabiegu. Wykorzystywanie jedynie bezpośredniej metody oznaczania rtęci $w$ glebie nie jest przydatne podczas prowadzenia oceny efektywności stabilizacji metalicznej rtęci w glebie w postaci HgS. Do oceny efektywności zabiegu immobilizacji konieczne jest zastosowanie metody specjacyjnej, pozwalającej na oznaczenie rtęci trwale związanej w postaci HgS lub tej niezwiązanej, mającej zdolność do emisji. W Zakładzie Ochrony Środowiska INiG - PIB opracowano dwie laboratoryjne metody pomiaru wielkości emisji rtęci, służące do oceny efektywności laboratoryjnych testów możliwości zastosowania siarki jako stabilizującej domieszki do gleb zanieczyszczonych rtęcią $[8,9$, 23, 25]. Przy wykorzystaniu tych metod można w pośredni sposób wyznaczyć ilość zawartej w glebie rtęci zdolnej do emisji. Spośród dwóch opracowanych metod laboratoryjnych pomiaru wielkości emisji rtęci z gleby metoda z zastosowaniem czujnika w postaci złotej blaszki w kolbie szklanej jest rekomendowana jako przydatna w pośredniej metodzie oznaczania zawartości rtęci w glebie. Metoda ta może być używana do oznaczania w sposób pośredni zawartości rtęci w glebie, ma jednak zastosowanie jedynie w przypadku oceny zanieczyszczenia gleby rtęcią zdolną do emisji, tzn. w praktyce można ją wykorzystać, gdy głównym zanieczyszczeniem jest rtęć metaliczna. Przy użyciu tej metody przed i po zastosowanym zabiegu można w sposób różnicowy prowadzić ocenę efektywności procesu immobi- lizacji rtęci. Przykładowe wyniki oceny efektywności procesu remediacji gleby zanieczyszczonej rtęcią przeprowadzonej laboratoryjną metodą pomiarów emisji rtęci przy zastosowaniu czujników w kolbach przedstawione zostały w tablicy 3 .

Analiza danych zawartych w tablicy 3 pokazuje, że użycie rozdrobnionej siarki jako substancji stabilizującej rtęć metaliczną w glebie jest efektywną metodą immobilizacji tego pierwiastka, a tym samym sposobem ograniczania jego migracji do innych elementów środowiska naturalnego.

Efektywność przeprowadzonego zabiegu immobilizacji rtęci w glebie oceniono również w warunkach polowych. Do oceny zastosowano metodę pomiarów wielkości emisji rtęci z zastosowaniem czujników pasywnych konstrukcji własnej INiG - PIB. Wyniki pomiarów uzyskane tą metodą zostały zobrazowane na rysunku 1. Efekt stabilizacji rtęci w postaci $\mathrm{HgS}$ jest widoczny już 24 godziny po przeprowadzeniu zabiegu remediacji.

Wyniki uzyskane po 24 godzinach od przeprowadzenia zabiegu remediacji dowodzą, że wielkość emisji została ograniczona o $26 \div 92 \%$. Powtórzone pomiary po 21 i 90 dniach od wykonania zabiegu pokazują, że wielkość emisji została ograniczona o $80 \div 99 \%$.

Tablica 3. Wyniki oceny efektywności procesu remediacji gleby zanieczyszczonej rtęcią (immobilizacja rtęci za pomocą rozdrobnionej siarki) przeprowadzonej laboratoryjną metodą pomiarów wielkości emisji rtęci przy zastosowaniu czujników w kolbach

\begin{tabular}{|c|c|c|}
\hline $\begin{array}{c}\text { Czas pobrania próbki } \\
\text { gleby/gruntu }\end{array}$ & $\begin{array}{c}\text { Masa } \mathrm{Hg} \text { zasorbowana } \\
\text { na czujniku } \\
{[\mathrm{ng}]}\end{array}$ & $\begin{array}{c}\text { Szacowana zawartość Hg } \\
\text { metalicznej w glebie } \\
{[\mathrm{mg} / \mathrm{kg}]}\end{array}$ \\
\hline \multicolumn{3}{|c|}{ MIEJSCE A } \\
\hline \multirow{3}{*}{ Przed zabiegiem remediacji } & 293,00 & $>300$ \\
\hline & 523,00 & $>300$ \\
\hline & 86,00 & $150 \div 300$ \\
\hline \multirow{3}{*}{$\begin{array}{l}24 \text { godziny po zabiegu } \\
\text { remediacji }\end{array}$} & 0,97 & $<15$ \\
\hline & 0,37 & $<15$ \\
\hline & 0,47 & $<15$ \\
\hline \multirow{3}{*}{90 dni po zabiegu remediacji } & 1,17 & $<15$ \\
\hline & 1,10 & $<15$ \\
\hline & 1,64 & $<15$ \\
\hline \multicolumn{3}{|c|}{ MIEJSCE B } \\
\hline \multirow{3}{*}{ Przed zabiegiem remediacji } & 308,00 & $>300$ \\
\hline & 318,00 & $>300$ \\
\hline & 317,00 & $>300$ \\
\hline \multirow{3}{*}{$\begin{array}{l}24 \text { godziny po zabiegu } \\
\text { remediacji }\end{array}$} & 0,18 & $<15$ \\
\hline & 0,13 & $<15$ \\
\hline & 0,29 & $<15$ \\
\hline \multirow{3}{*}{90 dni po zabiegu remediacji } & 26,10 & $15 \div 30$ \\
\hline & 24,90 & $15 \div 30$ \\
\hline & 7,80 & $<15$ \\
\hline
\end{tabular}




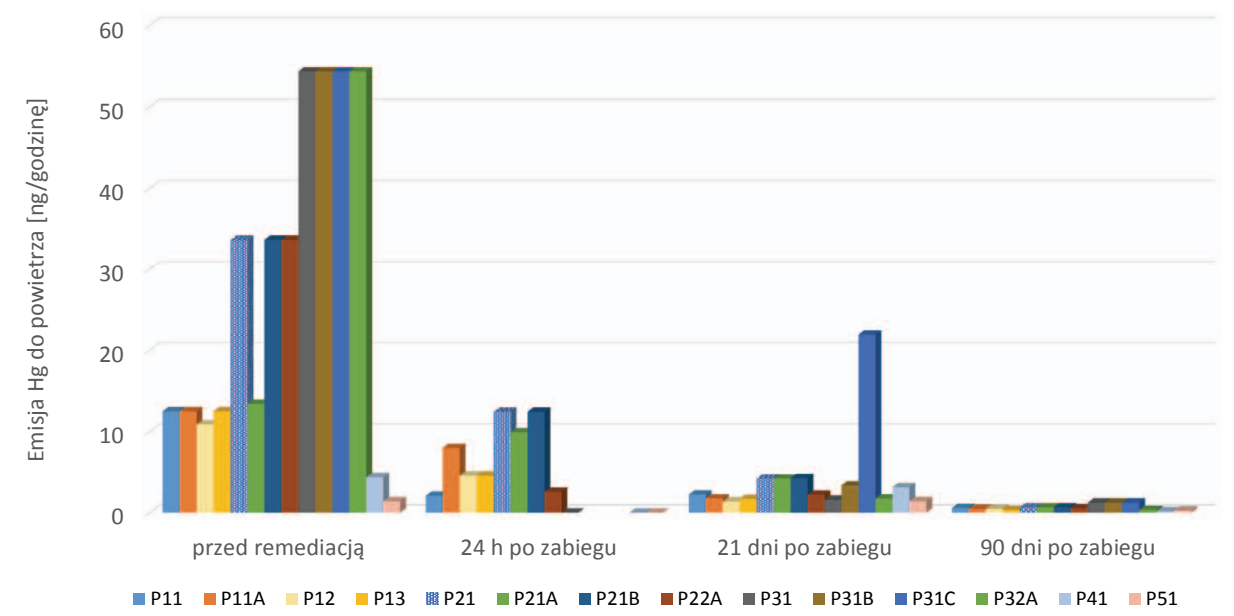

Rys. 1. Zmiana wielkości emisji rtęci z gleby do powietrza w wyniku zastosowania zabiegu immobilizacji rtęci w glebie

\section{Podsumowanie i wnioski}

Ograniczanie wielkości emisji rtęci do powietrza stanowi obecnie istotne zagadnienie w świetle prowadzonej prośrodowiskowej polityki światowej. Działania związane zarówno z identyfikacją miejsc zanieczyszczonych tym pierwiastkiem, jak i ograniczeniem wielkości jego emisji do powietrza są priorytetowe. W związku z tym przygotowanie prawidłowego programu monitoringu miejsc zanieczyszczonych rtęcią i zastosowanie odpowiednio dobranych metod remediacji gruntów jest również ważnym zagadnieniem. W tym kontekście opracowane i zwalidowane w Zakładzie Ochrony Środowiska INiG - PIB metody są przydatnym narzędziem podczas prowadzenia monitoringu zanieczyszczenia rtęcią metaliczną na terenach przemysłowych oraz oceny efektywności zabiegów remediacji gruntów zanieczyszczonych tym pierwiastkiem. Metody te to proste i tanie pośrednie metody pomiarów wielkości emisji rtęci z niewielkich obszarowo miejsc zanieczyszczonych rtęcią, wykorzystujące czujniki w kolbach (warunki laboratoryjne) oraz czujniki pasywne konstrukcji INiG - PIB (warunki polowe).

Opracowano na podstawie wyników badań ze środków własnych INiG - PIB oraz wyników badań uzyskanych podczas realizacji projektu nr II.P.10 pt. Opracowanie strategii występowania oraz likwidacji lokalnych skażeń rtęcia, występujących na terenie działalności przemystowej branży górnictwa nafty i gazu, będącego częścią III etapu programu wieloletniego Poprawa bezpieczeństwa i warunków pracy, finansowanego w latach 2014-2016 w zakresie badań naukowych i prac rozwojowych ze środków Ministerstwa Nauki i Szkolnictwa Wyższego/Narodowego Centrum Badań i Rozwoju (nr umowy z Narodowym Centrum Badań i Rozwoju DZP/PBiWP-III/2014). Koordynator programu: Centralny Instytut Ochrony Pracy - Państwowy Instytut Badawczy.

Prosimy cytować jako: Nafta-Gaz 2016, nr 8, s. 626-631, DOI: 10.18668/NG.2016.08.06

Artykuł nadesłano do Redakcji 1.02.2016 r. Zatwierdzono do druku 6.05.2016 r.

Artykuł powstał na podstawie referatu zaprezentowanego na Konferencji Naukowo-Technicznej FORGAZ 2016 „Techniki i technologie dla gazownictwa - pomiary, badania, eksploatacja”, zorganizowanej przez INiG - PIB w dniach 13-15 stycznia 2016 r. w Muszynie.

\section{Literatura}

[1] Alberta Research Council Inc.: Potential Release of Heavy Metals and Mercury from UOG Industry into the Ambient Environment-Literature Review. Final report. October 16, 2009.

[2] Boschee P.: Advancements in the removal of Mercury from crude oil. Oil and Gas Facilities 2013, vol. 2, issue 2, s. 181.

[3] Gostomczyk M. A., Jędrusik M., Świerczok A.: Ograniczenie emisji rtęci z procesów spalania węgla. [W:] Musialik-Piotrowska A., Rutkowski J. D. (red.): Współczesne osiagnięcia w ochronie powietrza atmosferycznego. Materiały z X Konferencji POL-EMIS, Wrocław 2010, s. 135-144.

[4] Gworek B., Bemowska O., Dmuchowski W., Szewczyk A., Wrzostek-Jakubowska J.: Źródła uwalniania rtęci do środowiska. Regulacje prawne. Monografia IOŚ - PIB, Warszawa 2013.

[5] Hławiczka S.: Rtęć w środowisku atmosferycznym. Works \& Studies - Prace i Studia nr 73. Zabrze: Instytut Podstaw Inżynierii Środowiska PAN, 2008.

[6] Janocha A.: Badania procesów korozji w odwiertach o dużej zawartości rtęci. Nafta-Gaz 2011, nr 3, s. 171-174.

[7] Kocman D., Horvat M., Pirrone N., Cinnirella S.: Contribution 
of contaminate sites to the global mercury budget. Environmental Research 2013, vol. 125, s. 160-170.

[8] Krasińska A., Król A.: Zastosowanie czujnika pasywnego własnej konstrukcji do wyznaczania stężenia rtęci w powietrzu, emisji rtęci z elementów środowiska oraz zawartości rtęci $w$ glebie. Nafta-Gaz 2010, nr 6, s. 486-492.

[9] Krasińska A., Szlęk M.: Problemy zwiazane z zanieczyszczeniem środowiska glebowego rtęcia na terenie działalności branży górnictwa naftowego i gazownictwa. Nafta-Gaz 2008, nr 5, s. 303-312.

[10] Król A., Krasińska A., Kukulska-Zając E.: Rtęć w środowisku-najnowsze wytyczne zwiąane z gospodarowaniem zasobami rtęci. Chemik 2014, vol. 68, nr 11, s. 973-978.

[11] Kubica K., Kubica R., Pye S., Pacyna J. M., Woodfield M.: Emisja rtęci $z$ instalacji spalania matej mocy. [W:] Konieczyński J. (red.): Ochrona powietrza w teorii i praktyce. T. 1, 2006, s. 149-157.

[12] Lang D., Gardner M., Holmes J.: Mercury arising from oil and gas production in the United Kingdom and UK continental shelf. Report by Dept. of Earth Sciences. University of Oxford, 2012.

[13] Lubaś J.: Rtęć w permsko-karbońskich gazach ziemnych Niżu Polskiego. Prace Instytutu Górnictwa Naftowego i Gazownictwa 1986, nr 56.

[14] Macuda J., Zawisza L.: Badanie gleb i gruntów w rejonie instalacji uzdatniania gazu ziemnego zanieczyszczonego rtecia; Wiertnictwo, Nafta, Gaz 2010, t. 27, z. 1-2, s. 261-267.

[15] Macuda J., Zawisza L.: Ocena stanu środowiska gruntowego w rejonie instalacji technologicznych kopalni gazu ziemnego ,Radlin”. Wiertnictwo, Nafta, Gaz 2008, t. 25, z. 2 , s. 503-509.

[16] Ministerstwo Środowiska: Najlepsze Dostępne Techniki (BAT). Wytyczne dla Branzy Chemicznej w Polsce. Przemyst Chloro-Alkaliczny. Warszawa, sierpień 2005.

[17] Ministry of Human Resources, Malaysia: Guidelines on Mercury Management in Oil and Gas Industry 2011.

[18] Mniszek W., Zielonka U.: Wskaźniki emisji rtęci do powietrza atmosferycznego. Ochrona Powietrza i Problemy Odpadów 1995, t. 29, nr 6, s. 178-181.

[19] Norwegian Oil and Gas: Norwegian Oil and Gas. Recommended guidelines for handling mercury. 2012, https://www. norskoljeoggass.no/Global/Retningslinjer/HMS/Arbeidsmil$\mathrm{j} \% \mathrm{C} 3 \% \mathrm{~B} 8 / 132 \% 20 \mathrm{Kvikks} \% \mathrm{C} 3 \% \mathrm{~B} 8 \mathrm{lv} / 132 \% 20 \mathrm{Recommen}-$ ded $\% 20$ guidelines $\% 20$ for $\% 20$ handling $\% 20$ mercury $\% 20$ eng,\%2010.09.2012.pdf (dostęp: lipiec 2014).

[20] Pacyna E. G., Pacyna J. M.: Global emission of Mercury from anthropogenic sources in 1995. Water, Air and Soil Pollution 2002, vol. 137, s. 149-165.

[21] Pacyna E. G., Pacyna J. M., Sundseth K., Munthe J., Kindbom K., Wilson S.: Global emission of mercury to the atmosphere from anthropogenic sources in 2005 and projection to 2020. Atmospheric Environment 2010, vol. 44, issue 20, s. 24872499.

[22] Pacyna J. M.: Emission factors of atmospheric elements. [W:] Nriagu O., Davidson C. (eds.): Toxic metals in the atmosphere. New York, John Wiley \& Sons, 1986, s. 1-32.

[23] Steczko K., Rachwalski J., Krasińska A.: Skażenia gleby rtęcia w górnictwie nafty i gazu - ocena wielkości emisji rtęci do atmosfery i efektywności jej ograniczenia $w$ wyniku stabilizacji siarka. Nafta-Gaz 2009, nr 10, s. 782-788.

[24] UNEP: Global Mercury Assessment 2013: Sources, Emissions, Releases and Environmental Transport 2013. UNEP Chemicals Branch, Geneva, Switzerland.

[25] Wang J., Feng X., Anderson C. W., Xing Y., Shang L.: Remediation of mercury contaminated sites - a review. Journal of Hazardous Materials 2012, vol. 221-222, s. 1-18.

\section{Akty prawne i normatywne}

[26] Minamata Convention on Mercury 2013, UNEP, http://www. mercuryconvention.org

[27] PN-C-04752:2011 Gaz ziemny - Jakość gazu w sieci przesytowej.

[28] PN-C-04753:2011 Gaz ziemny - Jakość gazu dostarczanego odbiorcom z sieci dystrybucyjnej.

[29] Rozporządzenie Ministra Gospodarki z dnia 2 lipca 2010 r. w sprawie szczegółowych warunków funkcjonowania systemu gazowego (Dz. U. Nr 133, poz. 891).

[30] Rozporządzenie Ministra Srodowiska z dnia 30 kwietnia 2008 r. w sprawie kryteriów wystapienia szkody w środowisku (Dz. U. Nr 82, poz. 501).

[31] Rozporządzenie Ministra Środowiska z dnia 4 czerwca 2008 r w sprawie rodzajów działań naprawczych oraz warunków i sposobu ich prowadzenia (Dz. U. Nr 103, poz. 664).

[32] Rozporządzenie Ministra Środowiska z dnia 9 września 2002 r. w sprawie standardów jakości gleby oraz standardów jakości ziemi (Dz. U. Nr 165, poz. 1359).

[33] Ustawa z dnia 13 kwietnia 2007 r. o zapobieganiu szkodom w środowisku i ich naprawie (Dz. U. Nr 75, poz. 493 $\mathrm{z}$ późn. $\mathrm{zm}$.)

[34] Ustawa $z$ dnia 27 kwietnia 2001 r. - Prawo ochrony środowiska (Dz. U. Nr 62, poz. 627 z późn. zm.).

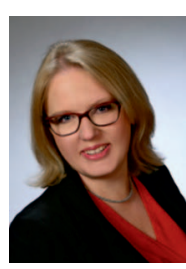

Mgr Anna KRÓL

Starszy specjalista badawczo-techniczny w Zakładzie Ochrony Środowiska.

Instytut Nafty i Gazu - Państwowy Instytut Badawczy

ul. Lubicz 25 A

31-503 Kraków

E-mail:anna.krol@inig.pl

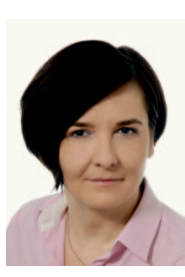

Dr Ewa KUKULSKA-ZAJĄC

Adiunkt; kierownik Zakładu Ochrony Środowiska. Instytut Nafty i Gazu - Państwowy Instytut Badawczy ul. Lubicz 25 A

31-503 Kraków

E-mail:kukulska@inig.pl



Dr hab. inż. Jan MACUDA

Prof. nadzw. AGH

Prodziekan ds. Studiów Niestacjonarnych i Doktoranckich na Wydziale Wiertnictwa, Nafty i Gazu. Akademia Górniczo-Hutnicza im. St. Staszica w Krakowie, Katedra Inżynierii Naftowej al. Mickiewicza 30, 30-059 Kraków E-mail:macuda@agh.edu.pl 